\title{
Methicillin-Susceptible and Methicillin-Resistant Staphylococcus aureus from the Retail Meat Shops and Customers
}

\author{
Asima Zehra*, Maliha Gulzar, Randhir Singh and Simranpreet Kaur \\ ${ }^{1}$ School of Public Health and Zoonoses, Guru Angad Dev Veterinary and Animal Sciences \\ University (GADVASU), Ludhiana-141004, Punjab, India \\ *Corresponding author
}

\section{Keywords}

Staphylococcus aureus, Multidrug resistance, Epsilometer test, MRSA, BORSA, Swab

Article Info

Accepted:

15 March 2019

Available Online:

10 April 2019

A B S T R A C T

This study was completed to know the prevalence of Methicillin-Susceptible (MSSA) and Methicillin-Resistant S. aureus (MRSA) in swab samples from retail meat shops (RM) and customers (CU) in five districts of Punjab, India. An aggregate of 182 swabs samples was aseptically collected from RM shops and customers. The collected samples were processed for an isolation of $S$. aureus isolates. The phenotypic resistance of $S$. aureus isolates was most noteworthy to Penicillin (PEN, 97.83\%) trailed by Ciprofloxacin (CPH, 56.52\%), Tetracycline (TET, 36.96\%), Trimethoprim-Sulfamethoxazole (TSH, 34.78\%) and Erythromycin (ERY, 17.39\%). However, low resistance was observed to Clindamycin, Chloramphenicol, Oxacillin, Ceftriaxone, and that fluctuated from $2 \%-7 \%$. None of the isolates was phenotypically resistant to vancomycin (MIC $0.5-2 \mu \mathrm{g} / \mathrm{ml}$ ). A large portion of S. aureus isolates $(58.69 \%, 95 \%$ CI 43.63-61.93) were Multi-drug resistant (MDR) and carried resistant genes to penicillin (blaZ), oxacillin (mecA), gentamicin (aacA-aphD), erythromycin $(e r m B, e r m \mathrm{C})$ and tetracycline $($ tet $\mathrm{K}$, tet $\mathrm{M})$. Two $S$. aureus isolates were borderline oxacillin resistant (BORSA) with MIC $4 \mu \mathrm{g} / \mathrm{ml}$ and one isolate was MRSA $(\mathrm{Oxacillin}$ MIC $16 \mu \mathrm{g} / \mathrm{ml})$ with a genotypic profile, mec $\mathrm{A}^{+}$blaZ $\mathrm{Z}^{+}$aac $\mathrm{A}-a p h \mathrm{D}^{+}$tet $\mathrm{K}^{+} e r m \mathrm{C}^{+}$. Among the erythromycin-resistant or intermediate resistant isolates, none expressed inducible macrolide lincosamide and streptogramin $\left(\mathrm{MLS}_{\mathrm{B}}\right)$ phenotype (ERY+/CLI-, D+) except for one MSSA isolates from CU hand swab sample that demonstrated a constitutive $\mathrm{MLS}_{\mathrm{B}}$ phenotype (Erm+/Cli+, D-).

\section{Introduction}

Antibiotic resistance and its exchange to different microorganisms are turning into a rising and serious pattern in developing countries like India. Community related sources are one such source that are imperative in harboring and dissemination of drug resistant microorganisms like $S$. aureus. $S$. aureus is universal in nature and ordinarily present on the skin and mucous membrane of animal and human, in soil and water (Irlinger 2008). It is likewise an imperative food-borne pathogen (Morgan 2008). In spite of the fact 
that it could be found in other animal and environment, a human is the noteworthy reservoir for $S$. aureus (Moellering, 2006). $S$. aureus resistance to oxacillin carrying mecA gene, presently known as MRSA, was first reported in the year 1961 and from that point forward it has been reported in isolates from hospitals, food, animals, community and environment (Ogata et al., 2012). MRSA isolates have been recognized in people in the community who do not have the conventional risk factors for $S$. aureus infection.

The CA-MRSA infections are of specific general wellbeing concern since they result in serious infections including necrotizing fasciitis and necrotizing pneumonia. The high morbidity, mortality, and cost of care related with organism features the requirement for public health agencies, hospitals, and other research facilities to precisely recognize these microorganisms.

Before, the development of MRSA infection was for all intents and purposes constrained to individuals who had history of ongoing hospitalization. Other than its presence in hospital environment, MRSA has likewise been reported from community settings (Roberts et al., 2011). MRSA has been isolated from understudy homes, university campus and public transportation system in the community (Roberts et al., 2011).

The development of antibiotic resistance in India is a major issue as antibiotic resistance particularly MRSA has been reported from hospitals in India (INSAR 2013, Nadig et al., 2012, D'Souza et al., 2010). However, antibiotic resistance of $S$. aureus isolates from retail meat shops and customers has not been pursued aggressively, particularly in Punjab. Consequently, the point of this study was to determine the prevalence, MRSA and futrthermore characterize AR pattern of $S$. aureus phenotypically and genotypically.

\section{Materials and Methods}

\section{Collection of samples}

A total of 182 swab samples from retail meat shops and customers were collected for the isolation of $S$. aureus from 5 districts of Punjab, India. Swab samples from retail meat shops (RM) included samples from chopping block (34), butcher's hand (37), and chopping knife (38). Region wise collection of different swab samples in the present study is given in Table 1. Swabs were transported back to the laboratory on ice and handled for isolation of $S$. aureus within 6 hours of collection.

\section{Isolation and identification of $S$. aureus}

Isolation of $S$. aureus from the swab samples was endeavored according to method suggested by Bacteriological Analytical Manual 2012 (Bennett and Lancette, 2001) after making necessary modifications according to Zehra et al., 2017. Colonies with typical morphology were then exposed to Gram staining and catalase test. Gram and catalase positive isolates were biochemically recognized as $S$. aureus utilizing the $\mathrm{HiStaph}^{\mathrm{TM}}$ Identification Kit (HiMedia Labs, Mumbai). These $S$. aureus isolates were purified and maintained in $20 \%(\mathrm{v} / \mathrm{v})$ glycerol at $-20^{\circ} \mathrm{C}$.

\section{Antibiotic susceptibility testing of $S$. aureus isolates}

The antibiotic susceptibility testing (AST) of $S$. aureus isolates was performed by the Epsilometer test (E-test, Figure 1). All the $S$. aureus isolates were tested for their affectability to different antibiotics viz. Oxacillin, Penicillin, Tetracycline, Chloramphenicol, Co-trimazole, Ceftriaxone, Gentamicin, Erythromycin, Ciprofloxacin, and Vancomycin using Ezy MIC $^{\mathrm{TM}}$ strip (HiMedia Lab, Mumbai). AST for 
amoxicillin/clavulinic acid ( $\beta$-lactamases hyperproduction) and D-test (inducible clindamycin resistance) was performed by disc diffusion method according to CLSI guidelines (M100-S21).

\section{Identification of antibiotic-resistant genes}

All the $S$. aureus isolates were likewise screened for the presence of following antibiotic resistance genes: blaZ, mecA, aac $\mathrm{A}-a p h \mathrm{D}, \operatorname{erm}(\operatorname{erm} \mathrm{A}, \operatorname{erm} \mathrm{B}, \operatorname{erm} \mathrm{C})$, tet (efflux genes tetK and tetL, tet $M$ and tet $O$ of the ribosomal protection (RP) family) and van A encoding for Penicillin, Oxacillin, Gentamicin, Erythromycin, Tetracycline and Vancomycin resistance, respectively, by amplification of the existing gene utilizing multiplex Polymerase Chain Reaction (PCR) (Table 1).

A S. aureus strain ATCC 33591 and ATCC 25923 was used as MRSA (mec A +ve) and MSSA (mecA -ve) positive control, respectively. KU872013, KP834338/ KP834339, KP658721, KP658723, KP886833, KT454736, KT454737, S. aureus isolates were used as positive control for genes blaZ, aac $\mathrm{A}-a p h \mathrm{D}, t e t \mathrm{~K}, \operatorname{tet} \mathrm{L}$, tet $\mathrm{M}$, erm $\mathrm{B}$, erm $\mathrm{C}$, respectively.

The isolation of genomic DNA from $S$. aureus strains was done using $\mathrm{HiPurA}^{\mathrm{TM}}$ bacterial genomic DNA purification kit (HiMedia Lab, Mumbai). Each isolate was subjected to a separate multiplex PCR assays for a detection of each group (gp) of genes: gp1 (16S rDNA, nuc, mecA); gp2 (tet $\mathrm{K}$, tet $\mathrm{L}$, tet $\mathrm{M}$ and tet $\mathrm{O}) ; \operatorname{gp} 3$ (erm $\mathrm{A}, \operatorname{erm} \mathrm{B}, \operatorname{erm} \mathrm{C}$ and $a a c \mathrm{~A}-a p h \mathrm{D})$; gp4 (coa and blaZ) as detailed in Zehra et al., (2017). Separate PCR was run for vanA gene. The cycling conditions of multiplex PCR for gp1, gp2 and gp3 and of single PCR for vanA gene were as per methodology of Strommenger et al., 2003 (with little modifications as per Zehra et al.,
2017) and Saha et al., 2008, respectively. However, cycling condition for coa and blaZ was as per the methodology of Zehra et al., (2017).

\section{Statistical analysis}

Microsoft excel was used for statistical analysis. The categorical variables were compared using a Pearson Chi-squared or Fisher's exact test, as appropriate. Differences were considered significant when the $P$-value was $<0.05$.

\section{Results and Discussion}

\section{Prevalence of $S$. aureus}

A total 46 swab samples out of 182 were positive for $S$. aureus culturally and affirmed through genus and species-specific PCR, resulting in an overall prevalence of $25.27 \%$ (95\% CI 15.97-34.57; Table 2, Figure 2).

Among the swab samples from RM shops, $S$. aureus was frequently isolated from butcher's Knife $(47.37 \%)$ trailed by butcher's hand (45.94\%), chopping block (11.76\%) and CU hand $(9.6 \%)$ (Table 2). The recurrence of $S$. aureus isolation from butcher hands and knife were significantly different $(\mathrm{P}<0.05)$ than from $\mathrm{Cu}$ hands. The odds of finding $S$. aureus-positive swab samples from RM workers were at least 2 times higher than the hand of customers.

These outcomes of the present study feature the requirement for good hygiene amid transportation, dealing with at retail outlets and customers to diminish the risk of transmission of $S$. aureus.

\section{Antibiotic resistance of $S$. aureus}

Among $46 \mathrm{~S}$. aureus isolates from various swab samples, a large portion of the isolates 
showed resistance to Penicillin (PEN, 97.83\%) trailed by Ciprofloxacin ( $\mathrm{CPH}$, 56.52\%), Tetracycline (TET, 36.96\%), Trimethoprim-Sulfamethoxazole (TSH, 34.78\%) and Erythromycin (ERY, 17.39\%). Nonetheless, low resistance was seen to Clindamycin, Chloramphenicol, Oxacillin, Ceftriaxone, and that varied from 2\%-7\% (Table 3). None of the isolates was discovered resistant to Vancomycin.

Most of the S. aureus isolates $(58.69 \%, 95 \%$ CI 43.63-61.93) in the present study were resistant to atleast three antibiotics and they were designated as multidrug-resistant $S$. aureus (MDR). S. aureus isolates were resistant to antibiotics somewhere in the range 0 and 5 , with a median of 2 on account of $\mathrm{CU}$ hand swab samples and with a median of 3 on account of RM swab samples. However, the quantity of antibiotics to which $S$. aureus isolates were resistant did not vary significantly between swab samples ( $p>0.05$ ).

\section{Antibiotic resistance gene}

$S$. aureus isolate $(1 / 46=2.17 \%)$ was assigned as MRSA dependent on the presence of methicillin resistance gene (mecA, Figure 1). This MRSA isolates was found only in $\mathrm{CU}$ hand swab sample from Gurdaspur district $(0.55 \%, 1 / 182)$ which accounted for $1.37 \%$ (1/73) MRSA prevalence in CU hand swab samples.

MRSA in the food of animal origin and community settings represents a significant risk to human wellbeing. In this study, the $\mathrm{CU}$ hand swab sample was the only sample contaminated with MRSA. Regardless of sample size variations, these studies suggested that MRSA contamination of various source can change by location due to the difference in management practices, hygienic measures and molecular distinction may exist among MRSA isolates of different origin.
Isolates that was mecA positive, indicated resistance to oxacillin (MIC $16 \mu \mathrm{g} / \mathrm{ml}$ ). Nonetheless, two S. aureus (2/46, 4.35\%) isolates that were phenotypically resistant to oxacillin yet genotypically without mecA had MIC $4 \mu \mathrm{g} / \mathrm{ml}$ and assigned as Borderline Oxacillin Resistant $S$. aureus (BORSA). Martineau et al., (2000) likewise reported the presence of isolates that were phenotypically oxacillin resistant however negative for the $m e c$ A gene. Similarly, Pereira et al., (2009) found $38 \%$ of $S$. aureus isolates resistant to oxacillin yet just $0.68 \%$ of the isolates demonstrated the presence of the mecA gene. Borderline oxacillin-resistant $S$. aureus (BORSA) has been frequently observed phenotype amongst $S$. aureus isolates. These isolates are cefoxitin/ceftriaxone susceptible and do not carry the mec $\mathrm{A}$ or $m e c \mathrm{C}$ genes, however, are indicated oxacillin resistance MIC between 1-8 $\mu \mathrm{g} / \mathrm{ml}$ (Shore and Coleman 2013). Such pattern may be a direct result of hyperproduction of $\beta$-lactamases, a creation of typical PBP with modified binding capacity or variant of mecA gene (Martineau et al., 2000, Laurent et al., 2012). To bar the likelihood of hyperproduction of $\beta$-lactamase, amoxyclave antibiotic disk diffusion test was performed (Martineau et al., 2000). The results of this study showed that isolates from RM (oxacillin resistant, mecA negative) to be ceftriaxone susceptible and $\beta$-lactamases hyperproducers blaz $^{+}$and amoxicillin/clavulinic acid disc diffusion size $>20 \mathrm{~mm}$ ).

Gentamicin resistant isolates were observed just in RM swab samples $(3 / 39,7.69 \%)$ with MIC $16-32 \mu \mathrm{g} / \mathrm{ml}$. These isolates were positive for the aacA-aphD gene (Figure 3). On the other hand, $8.69 \%$ (4/46) S. aureus isolates possessed aacA-aphD gene yet were phenotypically sensitive to gentamicin. This might be because of the absence of expression or partial expression of $a a c\left(6^{\prime}\right) / a p h\left(2^{\prime \prime}\right)$ gene (Martineau et al., 2000, Choi et al., 2003). In 
this study, the aacA-aphD gene was found in MRSA isolates. This Gentamicin-resistant MRSA is ordinarily experienced in community isolates and is less as often as possible found among clinical isolates (Ida et al., 2001).

In the present study, tet $K$ and tet $M$ genes were present in S. aureus isolates (Figure 4). Of the total $S$. aureus isolates, $36.96 \%$ (17/46) were positive for tet $K$ and $4.35 \%(2 / 46)$ were positive for both $t e t K$ and $t e t M$ genes. None of the isolates were positive for tetL and tetO gene. An MRSA isolate was positive for the tetK/tet $M$ gene. The wide circulation of tet $\mathrm{K}$ and tet $\mathrm{M}$ among $S$. aureus and MRSA isolates have been connected to the way that these genes are situated on mobile genetic elements (Chopra and Roberts 2001). Among the Erythromycin resistant genes, just ermB and erm $C$ genes were present in $S$. aureus isolates (Figure 3). The majority of the S. aureus isolates that were carrying any of the erm genes demonstrated complete or intermediate resistance to Erythromycin.

Table.1 Primers used for detection of antibiotic resistant genes in $S$. aureus

\begin{tabular}{|c|c|c|c|}
\hline Gene & Oligonucleotide sequence $\left(5^{\prime}-3^{\prime}\right)$ & $\begin{array}{c}\text { Amplicon } \\
\text { size }\end{array}$ & Reference \\
\hline aacA-aphD & $\begin{array}{l}\text { TAA TCC AAG AGC AAT AAG GGC } \\
\text { GCC ACA CTA TCA TAA CCA CTA }\end{array}$ & 227 & $\begin{array}{l}\text { Strommenger } \\
\text { et al., (2003) }\end{array}$ \\
\hline erm $\mathrm{A}$ & $\begin{array}{l}\text { AAG CGG TAA ACC CCT CTG A } \\
\text { TTC GCA AAT CCC TTC TCA AC }\end{array}$ & 190 & $\begin{array}{l}\text { Strommenger } \\
\text { et al., (2003) }\end{array}$ \\
\hline ermB & $\begin{array}{l}\text { CTATCTGATTGTTGAAGAAGGATT } \\
\text { GTTTACTCTTGGTTTAGGATGAAA }\end{array}$ & 142 & $\begin{array}{l}\text { Martineau et } \\
\text { al., (2000) }\end{array}$ \\
\hline erm C & $\begin{array}{l}\text { AAT CGT CAA TTC CTG CAT GT } \\
\text { TAA TCG TGG AAT ACG GGT TTG }\end{array}$ & 299 & $\begin{array}{l}\text { Strommenger } \\
\text { et al., (2003) }\end{array}$ \\
\hline tetK & $\begin{array}{l}\text { GTA GCG ACA ATA GGT AAT AGT } \\
\text { GTA GTG ACA ATA AAC CTC CTA }\end{array}$ & 360 & $\begin{array}{l}\text { Strommenger } \\
\text { et al., (2003) }\end{array}$ \\
\hline tetM & $\begin{array}{l}\text { AGT GGA GCG ATT ACA GAA } \\
\text { CAT ATG TCC TGG CGT GTC TA }\end{array}$ & 158 & $\begin{array}{l}\text { Strommenger } \\
\text { et al., (2003) }\end{array}$ \\
\hline tetL & $\begin{array}{l}\text { GTCGTTGCGCGCTATATTCC } \\
\text { GTGAACGGTAGCCCACCTAA }\end{array}$ & 696 & $\begin{array}{l}\text { Huys et al., } \\
\text { (2005) }\end{array}$ \\
\hline tet $\mathrm{O}$ & $\begin{array}{l}\text { AATGAAGATTCCGACAATTT } \\
\text { CTCATGCGTTGTAGTATTCCA }\end{array}$ & 781 & $\begin{array}{l}\text { Huys et al., } \\
\text { (2005) }\end{array}$ \\
\hline mecA & $\begin{array}{l}\text { AAA ATC GAT GGT AAA GGT TGG C } \\
\text { AGT TCT GCA GTA CCG GAT TTG C }\end{array}$ & 532 & $\begin{array}{l}\text { Strommenger } \\
\text { et al., (2003) }\end{array}$ \\
\hline blaZ & $\begin{array}{l}\text { ACT TCA ACA CCT GCT GCT TTC } \\
\text { TGA CCA CTT TTA TCA GCA ACC }\end{array}$ & 173 & $\begin{array}{l}\text { Martineau et } \\
\text { al., (2000) }\end{array}$ \\
\hline $\operatorname{van} \mathrm{A}$ & $\begin{array}{l}\text { ATGAATAGAATAAAAGTTGC } \\
\text { TCACCCCTTTAACGCTAATA }\end{array}$ & 1032 & $\begin{array}{l}\text { Saha et al., } \\
\text { (2008) }\end{array}$ \\
\hline $\begin{array}{c}16 S r D N A \\
\text { (Staphylococcus } \\
\text { genus specific) }\end{array}$ & $\begin{array}{l}\text { CAG CTC GTG TCG TGA GAT GT } \\
\text { AAT CAT TTG TCC CAC CTT CG }\end{array}$ & 420 & $\begin{array}{l}\text { Strommenger } \\
\text { et al., (2003) }\end{array}$ \\
\hline Nuc & $\begin{array}{c}\text { GCGATTGATGGTGATACGGTT } \\
\text { AGCCAAGCCTTGACGAACTAAAGC }\end{array}$ & 279 & $\begin{array}{l}\text { Brakstad et } \\
\text { al., (1992) }\end{array}$ \\
\hline
\end{tabular}


Table.2 Prevalence of S. aureus in RM shops and CU hand samples from different districts of Punjab

\begin{tabular}{|c|c|c|c|c|c|}
\hline \multirow[t]{2}{*}{ Districts } & \multicolumn{4}{|c|}{ Swabs } & \multirow[b]{2}{*}{$\begin{array}{c}\text { Hand } \\
\text { (Customers) } \\
(\%)\end{array}$} \\
\hline & $\begin{array}{l}\text { Butcher Hand } \\
\qquad(\%)\end{array}$ & $\begin{array}{c}\text { Chopping } \\
\text { block } \\
(\%)\end{array}$ & $\begin{array}{c}\text { Butcher Knife } \\
(\%)\end{array}$ & $\begin{array}{c}\text { Total Swab } \\
\text { samples } \\
(\%)\end{array}$ & \\
\hline Ludhiana & $\begin{array}{c}4 / 6 \\
(66.7)\end{array}$ & $\begin{array}{l}1 / 5 \\
(20)\end{array}$ & $\begin{array}{c}2 / 7 \\
(28.57)\end{array}$ & $\begin{array}{c}7 / 18 \\
(38.89)\end{array}$ & $\begin{array}{c}1 / 15 \\
(6.67)\end{array}$ \\
\hline Amritsar & $\begin{array}{c}2 / 5 \\
(40.0)\end{array}$ & $\begin{array}{c}0 / 6 \\
(0.0)\end{array}$ & $\begin{array}{c}3 / 6 \\
(50.0) \\
\end{array}$ & $\begin{array}{c}5 / 17 \\
(29.41)\end{array}$ & $\begin{array}{c}2 / 16 \\
(12.5)\end{array}$ \\
\hline Gurdaspur & $\begin{array}{c}5 / 13 \\
(38.46)\end{array}$ & $\begin{array}{c}3 / 14 \\
(21.42)\end{array}$ & $\begin{array}{c}7 / 13 \\
(53.85)\end{array}$ & $\begin{array}{l}15 / 40 \\
(37.5)\end{array}$ & $\begin{array}{c}3 / 12 \\
(25.0)\end{array}$ \\
\hline Patiala & $\begin{array}{c}3 / 6 \\
(50.0)\end{array}$ & $\begin{array}{l}0 / 6 \\
(0)\end{array}$ & $\begin{array}{c}3 / 7 \\
(42.86)\end{array}$ & $\begin{array}{c}6 / 19 \\
(31.58)\end{array}$ & $\begin{array}{c}0 / 13 \\
(0)\end{array}$ \\
\hline Barnala & $\begin{array}{c}3 / 7 \\
(42.85)\end{array}$ & $\begin{array}{c}0 / 3 \\
(0.0)\end{array}$ & $\begin{array}{c}2 / 6 \\
(33.33)\end{array}$ & $\begin{array}{c}5 / 16 \\
(31.25)\end{array}$ & $\begin{array}{c}1 / 17 \\
(5.89)\end{array}$ \\
\hline Total & $\begin{array}{c}17 / 37 \\
(45.94)\end{array}$ & $\begin{array}{c}4 / 34 \\
(11.76)\end{array}$ & $\begin{array}{c}18 / 38 \\
(47.37)\end{array}$ & $\begin{array}{l}39 / 109 \\
(35.78)\end{array}$ & $\begin{array}{c}7 / 73 \\
(9.59)\end{array}$ \\
\hline
\end{tabular}

Table.3 Antibiotic resistance of $S$. aureus isolates isolated from RM shops and CU hand swab samples

\begin{tabular}{|c|c|c|c|}
\hline Antibiotic & $\begin{array}{l}\text { No. of isolates resistant* }(\%) \\
\qquad n=46\end{array}$ & $\begin{array}{l}\text { No. of isolates } \\
\text { resistant from } \\
\text { RM swab } \\
\text { samples } 1 \%) \\
\text { n=109 }\end{array}$ & $\begin{array}{c}\text { No. of isolates } \\
\text { resistant from } \\
\text { CU swab samples } \\
\begin{array}{c}(\%) \\
\text { n=73 }\end{array}\end{array}$ \\
\hline OXA & 2.17 & 0.00 & 1.37 \\
\hline PEN & 97.83 & 34.86 & 100.00 \\
\hline TET & 36.96 & 15.59 & 0.00 \\
\hline CLI & 2.17 & 0.00 & 1.37 \\
\hline CTR & 0.00 & 0.00 & 0.00 \\
\hline GEN & 6.52 & 2.75 & 0.00 \\
\hline ERY & 17.39 & 1.83 & 8.22 \\
\hline CPH & 56.52 & 21.10 & 4.11 \\
\hline TSH & 34.78 & 14.68 & 0.00 \\
\hline CHL & 4.35 & 0.00 & 2.74 \\
\hline VAN & 0.00 & 0.00 & 0.00 \\
\hline
\end{tabular}

OXA-oxacillin, PEN-penicillin, TET-tetracycline, CLI-clindamycin, CTR-ceftriaxone, GEN-gentamicin, ERYerythromycin, $\mathrm{CPH}$-ciprofloxacin, TSH-trimethoprim-sulfamethoxazole, CHL-chloramphenicol, VAN-vancomycin. 1-swab samples from hand/knife/chopping block.

* Resistant strains include only those that showed complete resistance n- no. of isolates under study

Note: For erythromycin resistance estimation only isolates showing complete resistance were consider although 14 other isolates were intermediate resistant. 
Fig.1 The Epsilometer test showing the interaction of the inhibition zone with the strip of a $S$. aureus for Ceftriaxone (CTR)

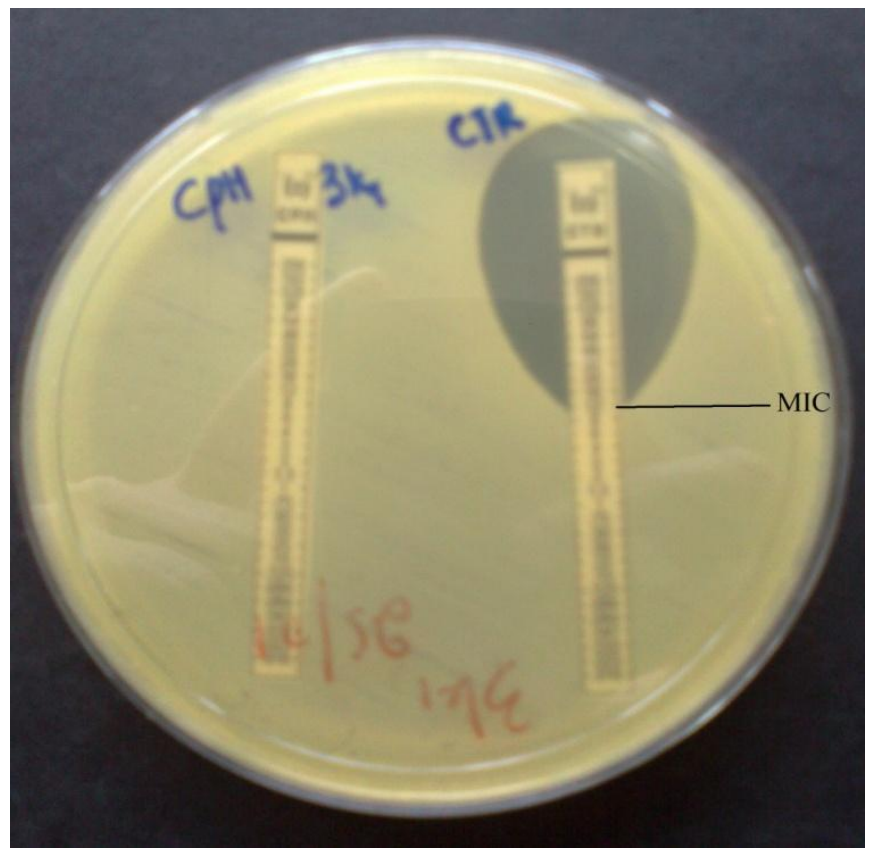

Fig.2 Agarose gel electrophoresis of PCR-amplified products using genus (16S rDNA420bp)/species-specific (nuc-279bp) and mecA (532bp) primer sets. lane M, 100-bp Plus DNA size marker; lane S, S. aureus ATCC 33591 reference strain; lane NTC, no template control

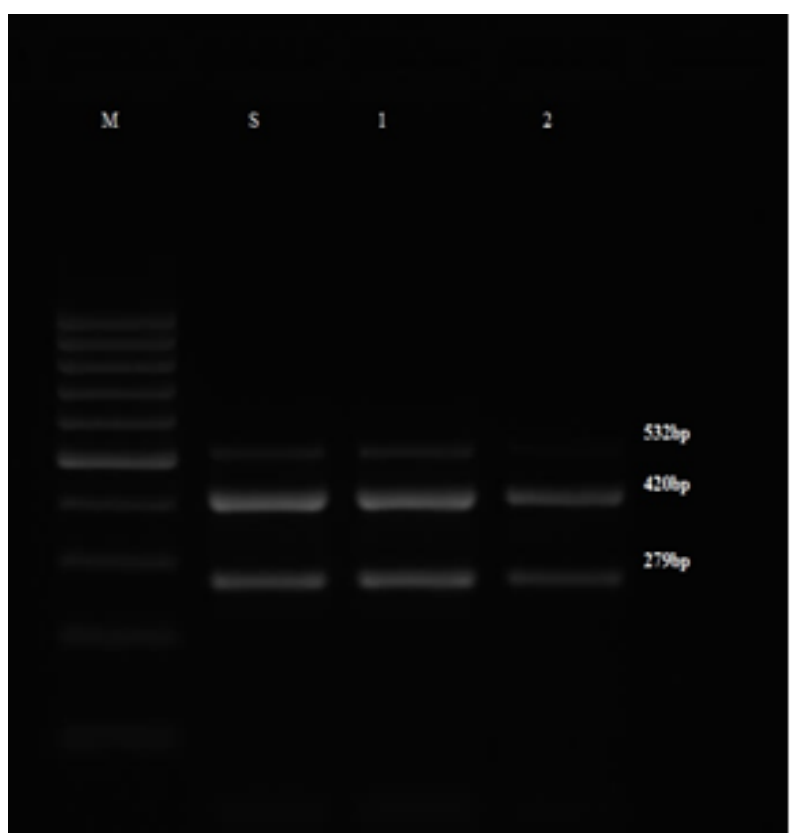


Fig.3 Agarose gel electrophoresis of PCR-amplified products using tetracyline resistance genes primer sets. Lanes 1-5, examined Staphylococcus aureus isolates; lane M, 100-bp Plus DNA size marker; lane S, Standard; lane NTC, no template control.

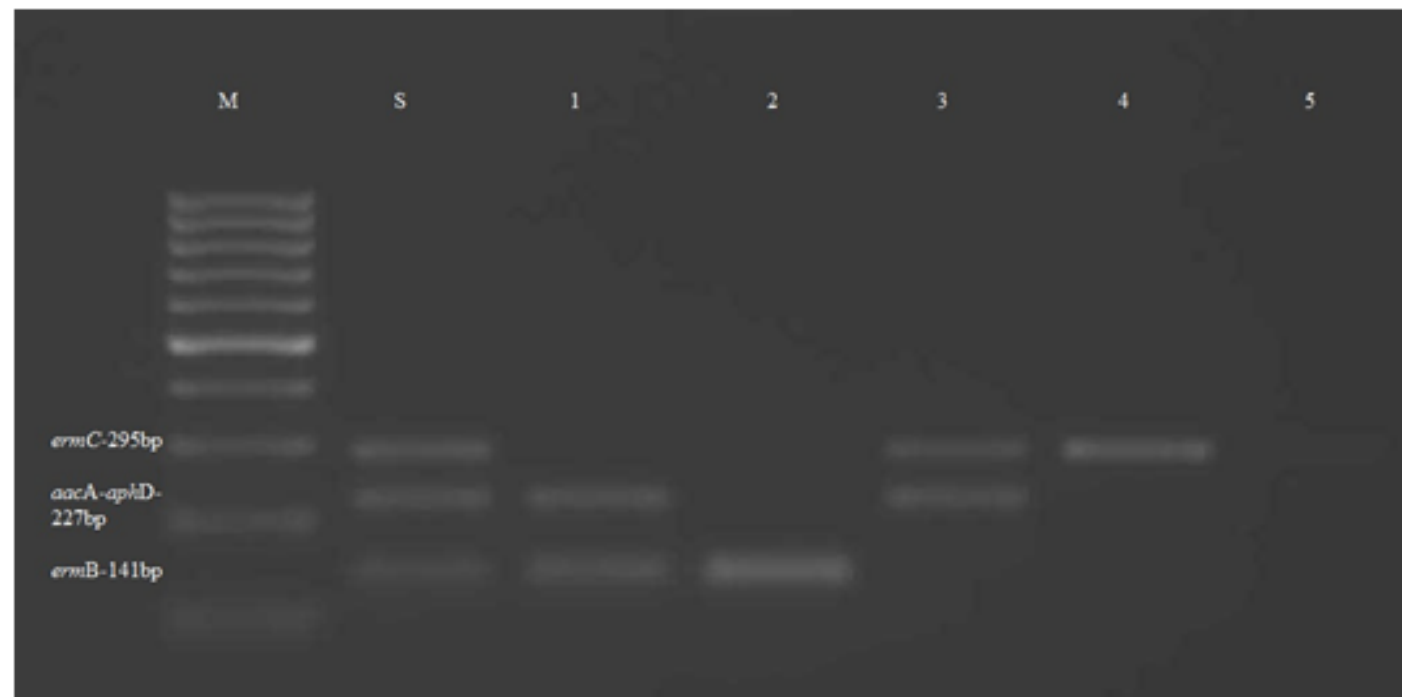

Fig.4 Agarose gel electrophoresis of PCR-amplified products using tetracyline resistance genes primer sets. Lanes 7-11, examined Staphylococcus aureus isolates; lane M, 100-bp Plus DNA size marker; lane S, Standard; lane NTC, no template control. Note: Isolate in the lane 9 was isolates from the meat sample not from swab samples.

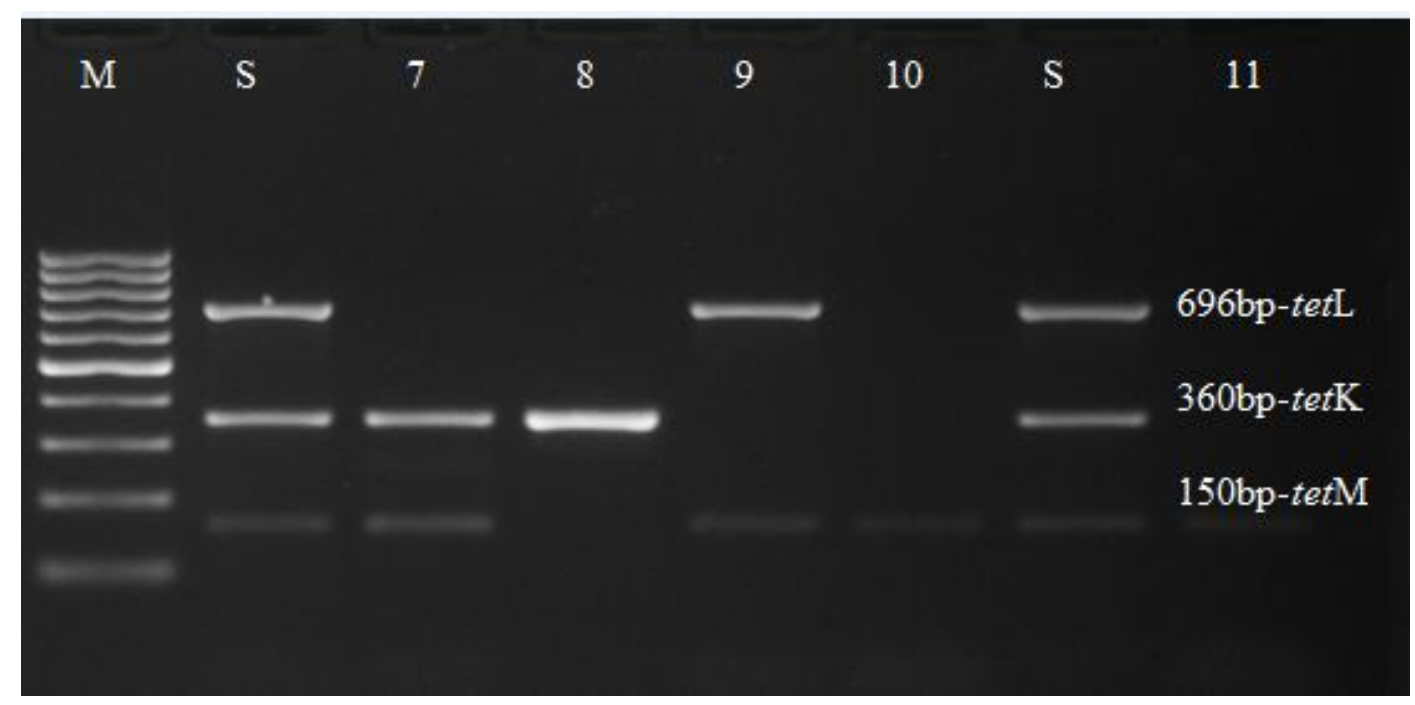


Fig.5 D-shaped zone of inhibition around the Clindamycin disk is designated as the D phenotype which is labeled as D+.

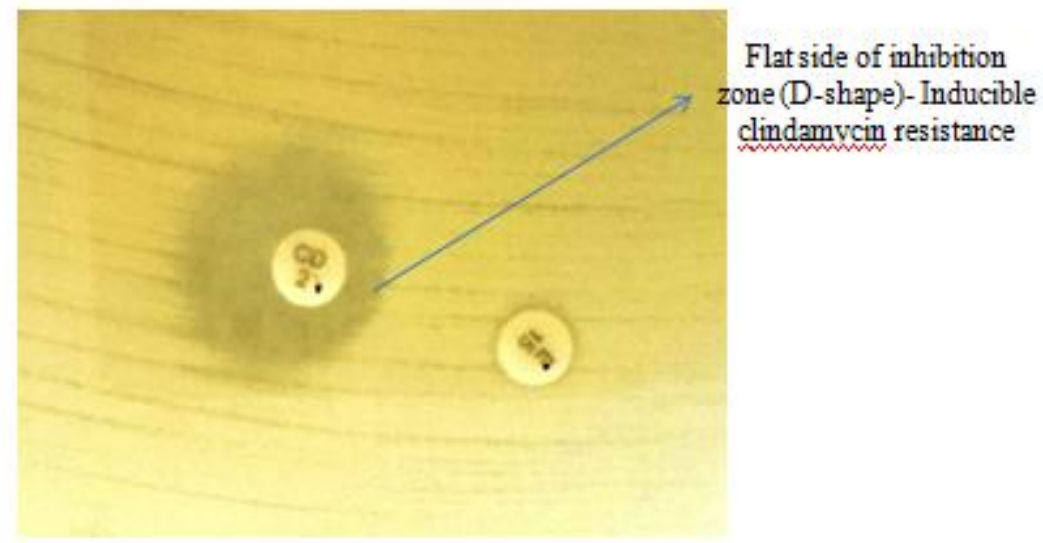

In this study, $19.57 \%(9 / 46)$ of the $S$. aureus isolates were genotypically negative yet demonstrated an intermediate resistance with MIC $\quad 1-2 \mu \mathrm{g} / \mathrm{ml}$ phenotypically. This intermediate resistance to Erythromycin could be because of different genes like $m s r A$ or novel gene ermTR (Seppa“la“ et al., 1998, Martineau et al., 2000). Similarly, Martineau et al., (2000) additionally reported two $S$. aureus isolates resistant to erythromycin phenotypically however not carrying any of the erm resistance genes. It was additionally seen that the isolates from the CU hands were complete resistant to erythromycin unlike samples from RM.

These isolates that were resistant $(\mathrm{R})$ or intermediate resistant (IR) to erythromycin in vitro tested for inducible clindamycin resistance (D-test, Figure 5). Among the 22 erythromycin-resistant (R+IR) $S$. aureus isolates, none demonstrated inducible $\mathrm{MLS}_{\mathrm{B}}$ phenotype (ERY+/CLI-, D+) aside from one MSSA (methicillin susceptible $S$. aureus) isolates from $\mathrm{CU}$ hand swab sample that showed a constitutive MLS $_{\mathrm{B}}$ phenotype (Erm+/Cli+, D-).

In conclusion, this is the short study of the prevalence of $S$. aureus and MRSA in RM and $\mathrm{CU}$ hand swab samples from five districts of Punjab. This study detailed a relatively high prevalence of $S$. aureus and high rates of antimicrobial resistance amongst the isolates. Just one isolate was MRSA and was isolated from the hand of the customer. The information of this study affirm the uneven conceivable sources of MRSA contamination in the food chain that can have a potential role in the dispersal of multidrug-resistant $S$. aureus isolates This study clearly shows the prerequisite of further investigation at the ranch, retail and customer levels including large sample size over time so as to all the more likely evaluate the presence and cause of MRSA in domesticated animals and the risk to livestock handlers and costomers in Punjab.

Practical measures ought to be taken to guarantee the wellbeing of our food products. Likewise, the present study uncovered the prevalence of BORSA that is of public health concern in light of the fact that the occurrences of BORSA have been accounted for in emergency clinics.

\section{Acknowledgement}

This work was financially supported at School of Public Health and Zoonoses, GADVASU under Rashtriya Krishi Vikas Yojana (RKVY). 


\section{Conflict of interest}

The authors declare that they have no competing interests.

\section{References}

Bennett R, and Lancette G. BAM: Staphylococcus aureus. Fda.gov. 2001; retrieved from https://www.fda.gov/ food/foodscienceresearch/laboratorymet hods/ucm071429.htm

Choi S M, Kim S H, Kim H J, Lee D G, Choi J H, Yoo J H, Kang J H, Shin W S, Kang M W. 2003. Multiplex PCR for the detection of genes encoding aminoglycoside modifying enzymes and methicillin resistance among Staphylococcus species. Journal of Korean medical Science, 18(5): 631-36.

Chopra I and Roberts M. 2001. Tetracycline antibiotics: mode of action, applications, molecular biology, and epidemiology of bacterial resistance. Microbiology and Molecular Biology Reviews 65:232-60.

D'Souza N, Rodrigues C, Mehta A. 2010. Molecular characterization of methicillin-resistant Staphylococcus aureus with emergence of epidemic clones of sequence type (ST) 22 and ST 772 in Mumbai, India. Journal of Clinical Microbiology 48: 1806-11.

Ida T, Okamoto R, Shimauchi C, Okubo T, Kuga A, Inoue M. 2001. Identification of aminoglycoside-modifying enzymes by susceptibility testing: epidemiology of methicillin-resistant Staphylococcus aureus in Japan. Journal Clinical Microbiology 39: 3115-21.

Indian Network for Surveillance of Antimicrobial Resistance (INSAR) group, India. 2013. Methicillin resistant Staphylococcus aureus (MRSA) in India: Prevalence \& susceptibility pattern. Indian Journal of Medical
Research 137: 363-69.

Irlinger F. 2008. Safety assessment of dairy microorganisms: Coagulase-negative staphylococci. International Journal of Food Microbiology 126: 302-10.

Laurent F, Chardon H, Haenni M, Bes M, Reverdy M E, Madec J Y, Lagier E, Vandenesch F, Tristan A. 2012. MRSA harboring mec A variant gene mecC in France. Emerging Infectious Disease 18: $1465-67$.

Martineau F, Picard J F, Lansac N, Menard C, Roy H P, Ouellette $\mathrm{M}$ and Bergeron $\mathrm{G}$ M. 2000. Correlation between the resistance genotype determined by multiplex pcr assays and the antibiotic susceptibility patterns of Staphylococcus aureus and Staphylococcus epidermidis. Antimicrobial Agents and Chemotherapy 44(2): 231-38.

Moellering R C. 2006. The Growing Menace of Community-Acquired Methicillin Resistant Staphylococcus aureus. Annals of Internal Medicine 144: 36870.

Morgan M. 2008. Methicillin-resistant Staphylococcus aureus and animals: Zoonosis or humanosis? The Journal of Antimicrobial Chemotherapy 62: 118187.

Nadig S, Velusamy N, Lalitha P, Kar S, Sharma S, and Arakere G. 2012. Staphylococcus aureus eye infections in two Indian hospitals: the emergence of ST772 as a major clone. Clinical Ophthalmology (Auckland, N.Z.) 6: 165-173

Ogata K, Narimatsu H, Suzuki M, Higuchi W, Yamamoto T, Taniguchi H. 2012. Commercially Distributed Meat as a Potential Vehicle for CommunityAcquired Methicillin-Resistant Staphylococcus aureus. Applied Environmental Microbiology 78(8): 2797-2802. 
Pereira V, Lopes C, Castro A, Silva J, Gibbs

$\mathrm{P}$ and Teixeira P. 2009. Characterization for enterotoxin production, virulence factors, and antibiotic susceptibility of Staphylococcus aureus isolates from various foods in Portugal. Food Microbiology 26:278-82.

Roberts M C, Soge O O, No D, Helgeson S E and Meschke J S. 2011. Characterization of methicillin-resistant Staphylococcus aureus isolated from public surfaces on a university campus, student homes and local community. Journal of Applied Microbiology 110: 1531-37.

Seppa"la" H, Skurnik M, Soini H, Roberts M and Huovinen H. 1998. A novel erythromycin resistance methylase gene (ermTR) in Streptococcus pyogenes. Antimicrobial Agents Chemotherapy
42:257-62.

Shore A, and Coleman D. Staphylococcal cassette chromosome mec: Recent advances and new insights. International Journal of Medical Microbiology 2013; 303(6-7): 350-359. http://dx.doi.org/10.1016/j.ijmm.2013.0 2.002

Strommenger B, Kettlitz C, Werner G and Witte W. 2003. Multiplex PCR assay for simultaneous detection of nine clinically relevant antibiotic resistance genes in Staphylococcus aureus. Journal of Clinical Microbiology 41: 4089-94.

Zehra A, Singh R, Kaur S and Gill JPS. 2017. Molecular characterization of antibioticresistant Staphylococcus aureus from livestock (bovine and swine). Veterinary World. 5: 598-604

\section{How to cite this article:}

Asima Zehra, Maliha Gulzar, Randhir Singh and Simranpreet Kaur. 2019. MethicillinSusceptible and Methicillin-Resistant Staphylococcus aureus from the Retail Meat Shops and Customers. Int.J.Curr.Microbiol.App.Sci. 8(04): 1929-1939. doi: https://doi.org/10.20546/ijcmas.2019.804.226 